\title{
Merdeka Belajar bagi Anak Kebutuhan Khusus di SLB Kumala Indah Padangsidimpuan
}

\author{
Asfiati1, Nur Imam Mahdi ${ }^{2}$ \\ 1,2Institut Agama Islam Negeri Padangsidimpuan \\ asfiati@iain-padangsidimpuan.ac.id
}

\begin{abstract}
ABSTRAK. Pemerintah melakukan perubahan pendidikan yaitu adanya Merdeka Belajar. Merdeka Belajar diharapkan dilaksanakan oleb semua jenis pendidikan termasuk anak berkebutuban kbusus diberikan kesempatan penuh untuk mendapatkan pendidikan dan pengajaran. Fokus penelitian ini yaitu sistem zonasi sebagai sistem Penerimaan Peserta Didik Baru (PPDB) dan asesement kemampuan minimum serta survey karakter. Metode penelitian adalah deskriptif kualitatif. Sumber data primer penelitian adalah kepala sekolah dan wakil kepala sekolah bidang kurikulum. Sumber data sekunder adalah 5 orang guru dan siswa di Sekolah Luar Biasa (SLB) Kumala Indah kota Padangsidimpuan. Peneliti mengumpulkan data melalui wawancara mendalam dan observasi, dokumentasi. Data dianalisa dengan teknik interaksi melalui reduksi data, penyajian data dan kesimpulan. Hasil penelitian ini menunjukan bahwa sistem zonasi PPDB telab dilakukan di Sekolah Luar Biasa (SLB) Kumala Indah kota Padangsidimpuan sebagai bukti mendukung program pemerintah. PPDB melalui jalur zonasi $50 \%$ terdiri dari 10 siswa.
\end{abstract}

Kata kunci: ABK, Belajar, Merdeka.

ABSTRACT. The government made a change in education as the existence of Merdeka Belajar. Free Learning is expected to be carried out by all types of education include children with special needs(ABK) given full opportunities to get education and donations. The focus of this research is the zoning system as a New Student Acceptance system (PPDB) and a minimum ability assessment and character survey. The research method is descriptive qualitative. Primary data sources of research are the principal and vice principals in the curriculum. Secondary data sources are 5 teachers and students in Kumala Indah Extraordinary School (SLB), Padangsidimpuan. Researchers collect data through indepth interviews and observations, organization. Data were analyzed by interaction techniques through data reduction, data presentation and conclusions. The results of this study show that the PPDB zoning system had been carried out at the Kumala Indah Special School (SLB) in the city of Padangsidimpuan as supporting evidence for the government program. PPDB through zoning 50\% consists of 10 students.

Keywords : ABK, Freedom, Learning. 


\section{PENDAHULUAN}

Perubahan merupakan bukti dinamisasi. Perubahan menunjukkan adanya perbaikan dan arah menuju kesempurnaan. Perbaikan dapat dilakukan dalam berbagai aspek. Aspek pendidikan, kebudayaan, ekonomi serta keamanan. Setiap aspek melibatkan banyak orang. Bidang pendidikan tentunya melibatkan pendidik, peserta didik dan pemerhati pendidikan. Pemerhati pendidikan memberikan kebijakan masukan terhadap pihak pembuat kebijakan dalam penyusunan kebijakan publik di bidang pendidikan. Pendidik melaksanakan kebijakan untuk suatu kemajuan. Peserta didik memperoleh keberhasilan pendidikan melalui pelaksanaan kebijakan. Peserta didik yang dimaksud mulai dari jenis dan jenjang pendidikan hingga satuan pendidikan. Satuan pendidikan melibatkan pendidikan formal, non formal dan informal. Satuan pendidikan meliputi lembaga pendidikan yang mendidik peserta didik yang normal dan berkebutuhan khusus. Satuan pendidikan termasuk lembaga pendidikan yang tergolong dalam pendidikan inklusi. Pendidikan inklusi memberikan kesempatan kepada anak seperti anak berkebutuhan khusus(Badiah et al., 2020). Anak berkebutuhan khusus juga mendapat kesempatan untuk mengenyam pendidikan. Pada semua jenjang, dari jenjang PAUD hingga jenjang pendidikan tinggi baik pada jalur formal maupun non formal.

Pendidikan di Indonesia senantiasa memperhatikan harapan setiap peserta didiknya. Peserta didik yang tergolong berkebutuhan khusus memperoleh hak yang sama dengan setiap warga negara lainnya. Regulasi Pendidikan yang tertuang di dalam Undang-undang Nomor. 20 Tahun 2003 tentang Sistem Pendidikan Nasional Pasal 32 disebutkan bahwa: "Pendidikan khusus (pendidikan luar biasa) merupakan pendidikan bagi peserta didik yang memiliki tingkat kesulitan dalam mengikuti proses pembelajaran karena kelainan fisik, emosional, mental, dan sosial, dan atau memiliki potensi kecerdasan dan bakat istimewa" (Indonesia, 2003).Hadirnya Undangundang Nomor. 20 Tahun 2003 tentang hak memperoleh pendidikan kepada setiap warga negara Indonesia tidak terkecuali kepada anak berkebutuhan khusus ABK). Warga negara Indonesia yang berkebutuhan khusus dan penyandang kelainan lainnya berpeluang penuh memperoleh pendidikan. Demikian halnya dalam diberlakukannya beberapa kebijakan pendidikan.

Kebijakan pendidikan sebagai perubahan untuk keberhasilan pendidikan. Salah satu kebijakan yang baru diretas oleh Menteri Pedidikan dan Kebudayaan adalah jargon "Merdeka Belajar". Merdeka belajar juga berlaku kepada peserta didik yang berkebutuhan khusus dan penyandang kelainan lainnya. Merdeka Belajar di Sekolah Luar Biasa berlaku kepada peserta didik juga pendidik dan lembaga pendidikannya. Adapun kebijakan-kebijakan yang termuat dalam "Merdeka Belajar" sebagai berikut:

1. "Ujian Sekolah Berbasis Nasional (USBN) diganti ujian (asesmen) Adapun maksud digantinya Ujian Sekolah Berbasis Nasional (USBN) menjadi asesmen sebagai alasan adanya pembatasan penerapan Undang-Undang Sistem Pendidikan Nasional yang memberikan keleluasaan bagi sekolah untuk menentukan kelulusan. Dalam kebijakan merdeka belajar diganti dengan ujian (asesmen) penyelenggaraannya diserahkan penuh kepada sekolah. Asesmen bertujuan menilai kompetensi peserta didik. Penilaian dilakukan secara komprehensif. Penilaian diukur setelah melaksanakan ujian berbentuk tes tertulis. Bentuk ujian seperti portofolio dan penugasan diberikan kepada peserta didik secara berkelompok dan individu. Portofolio berupa karya tulis.

2. Adanya kebijakan digantinya Ujian Nasional (UN). Peserta didik diuji dengan kompetensi penalaran. Dalam hal ini Ujian Nasional (UN) diganti dengan Asesmen Kompetensi Minimum dan Survei Karakter. Kebijakan merdeka belajar menjadikan pendidik lebih mempunyai hak prerogatif menilai hasil belajar siswa. Kebijakan merdeka belajar mengukur keberhasilan siswa berdasarkan Asesmen Kompetensi Minimum dan Survei 
Karakter tersebut. Kompetensi minimum siswa diukur dari aspek literasi dan numerasi. Adapun peserta didik yang melakukan asesmen kompetensi adalah siswa yang duduk di tengah jenjang sekolah (yaitu kelas 4 untuk jenjang Sekolah Dasar, kelas 8 untuk jenjang Sekolah Menengah Pertama dan kelas 11 untuk Sekolah Menengah Atas).

3. Format Rencana Pelaksanaan Pembelajaran (RPP) dirampingkan. Guru bebas memilih, membuat, menggunakan dan mengembangkan format RPP. Rencana Pelaksanaan Pembelajaran (RPP) berisi tujuan pembelajaran, kegiatan pembelajaran dan asesmen. Rencana Pelaksanaan Pembelajaran (RPP) hanya 1 halaman. Penulisan Rencana Pelaksanaan Pembelajaran (RPP) dilakukan dengan efisien dan efektif yang menjadikan guru punya waktu untuk mempersiapkan juga mengevaluasi proses pembelajaran itu sendiri.

4. Zonasi Penerimaan Peserta Didik Baru (PPDB) lebih fleksibel. Sistem zonasi dalam Penerimaan Peserta Didik Baru (PPDB) untuk mengakomodasi ketimpangan akses dan kualitas di berbagai daerah. Komposisi Penerimaan Peserta Didik Baru (PPDB) jalur zonasi dapat menerima siswa minimal 50 persen, jalur afirmasi minimal 15 persen, dan jalur perpindahan maksimal 5 persen. Untuk jalur prestasi atau sisa 0-30 persen lainnya disesuaikan dengan kondisi daerah. "Daerah berwenang menentukan proporsi final dan menetapkan wilayah zonasi,"(Adit, 2019)

Kebijakan merdeka belajar tersebut tentunya berlaku di setiap jenjang dan jenis pendidikan. Kebijakan merdeka belajar berlaku bagi pendidik dan peserta didik. Pendidikan di jenis Sekolah Luar Biasa juga ikut serta dalam mendukung program pemerintah dalam menggalakkan jargon merdeka belajar. Demikian halnya dengan pendidikan pada ABK di Sekolah Luar Biasa (SLB) Kumala Indah Padangsidimpuan. Sekolah Luar Biasa (SLB) tersebut dalam mendukung program Menteri Pendidikan dan Kebudayaan memulai pelaksanaannya secara menyeluruh pada tahun ajaran 2021 ini. Akan tetapi program Penerimaan Peserta Didik Baru (PPDB) telah dilaksanakan sejak sekolah SLB Kumala Indah didirikan. Pelaksanaan Program Zonasi Penerimaan Peserta Didik Baru (PPDB) di Sekolah Luar Biasa (SLB) Kumala Indah terlaksana di samping membantu program pemerintah juga mengakomodir ketimpangan akses dan kualitas di sekitar lingkungan sekolah.

Sekolah Luar Biasa (SLB) Kumala Indah Padangsidimpuan yang berdiri tiga tahun yang lalu tepat tahun 2016 telah mempunyai 21 siswa dengan beberapa jenis berkebutuhan khusus (Nuryaningsih, 2020). Tahun ajaran 2019/2020 ini 21 siswa tersebut tersebar dalam 7 rombongan belajar (Indah, 2020). Ketujuh rombongan belajar tersebut dibimbing oleh 5 orang guru/tenaga pengajar yang berstatus guru tetap yayasan (Situmeang, 2020) Perbandingan guru dan siswa tersebut menjadi kendala bagi pelaksanaan proses pembelajaran. Dalam hal ini guna mendukung dan mensukseskan program pemerintah dengan Merdeka Belajar Sekolah Luar Biasa (SLB) Kumala Indah Padangsidimpuan melakukan banyak hal. Salah satu yang diterapkan adalah sistem Penerimaan Peserta Didik Baru (PPDB) harus lebih disiasati mengingat jumlah siswa semakin tahun semakin meningkat. (Nuryaningsih, 2020b).

Berdasarkan fenomena yang ada kiranya penting mendeskripsikan tentang banyak hal yang dilakukan Sekolah Luar Biasa (SLB) Kumala Indah Padangsidimpuan dalam mendukung program pemerintah khususnya sistem zonasi Penerimaan Peserta Didik Baru (PPDB). Selanjutnya juga mengamati beberapa hal tentang pelaksanaan penyusunan Rencana Pelaksanaan Pembelajaran (RPP). Rencana Pelaksanaan Pembelajaran (RPP) sudah harus dimulai guru-guru di SLB Kumala Indah Padangsidimpuan mulai tahun ajaran 2020/2021 ini guna mendukung program 
pemerintah. Penulisan Rencana Pelaksanaan Pembelajaran (RPP) sudah dirancang sejak Program Merdeka Belajar diretas dan SLB Kumala Indah tinggal menindaklanjutinya sesuai dengan sosialisasi penerintah nantinya. Untuk lebih memahami merdeka belajar di SLB Kumala Indah Padangsidimpuan peneliti menelusuri dua hal, yaitu: sistem zonasi Penerimaan Peserta Didik Baru (PPDB) dan pelaksanaan penyusunan Rencana Pelaksanaan Pembelajaran (RPP) sesuai dengan kurikulum pendidikan anak berkebutuhan khusus.

\section{METODE PENELITIAN}

Penelitian ini dilaksanakan di Sekolah Luar Biasa (SLB) Kumala Indah Padangsidimpuan. Lokasi Sekolah berada $10 \mathrm{~km}$ dari pusat kota Padangsidimpuan. Waktu pelaksanaan penelitian pada tahun ajaran 2019/2020, tepatnya sejak awal penerimaan siswa baru hingga pelaksanaan ujian kenaikan kelas. Pendekatan penelitian menggunakan kualitatif deskriptif. Penelitian kualitatif dengan maksud menafsirkan fenomena yang terjadi secara latar alamiah (Anggito, Albi \& Setiawan, 2018).

Peneliti berusaha menggambarkan kegiatan yang dilakukan Sekolah Luar Biasa (SLB) Kumala Indah Padangsidimpuan dalam rangka mendukung program pemerintah Merdeka Belajar dan dampaknya bagi anak yang berkebutuhan khusus di sekolah tersebut. Berdasarkan latar alamiah maka sumber data penelitian ini adalah kepala sekolah dan wakil kepala sekolah bidang kurikulum sebagai instrumen kunci. Peneliti berupaya mencari data dengan memfokuskan pada kegiatan-kegiatan Penerimaan Peserta Didik Baru (PPDB) melalui sistem zonasi dan juga penyusunan Rencana Pelaksanaan Pembelajaran (RPP) dengan kurikulum pendidikan anak berkebutuhan khusus.(Luthfiyah, 2018). Pelaksanaan identifikasi dilanjutkan dengan mengintrepretasi seluruh fenomena untuk dijadikan satu paradigma (Asfi Manzilati, 2017). Dengan adanya informan kunci maka penelitian ini dibagi kepada dua sumber data. Adapun sumber data primer adalah kepala sekolah dan wakil kepala sekolah bidang kurikulum dan sumber data sekunder adalah guru tetap yayasan, ketua yayasan, orang tua siswa dan 21 siswa.

Teknik pengumpulan data penelitian ini adalah wawancara mendalam (in-depth interview) serta wawancara bertahap, observasi dan studi dokumentasi (Nursyaidah, 2018). Adapun teknik pengumpulan data dengan menggunakan tiga jenis pelaksanaan. Dimana data dianalisis dengan reduksi data, penyajian data dan kesimpulan (Nursyaidah, 2018).

\section{HASIL DAN PEMBAHASAN}

Merdeka belajar sebagai gagasan Menteri Pendidikan dan Kebudayaan merupakan upaya dalam peningkatan kemajuan pendidikan. Pendidikan yang maju merupakan hak semua warga negara Indonesia. Pendidikan yang berhasil juga harus dirasakan oleh anak berkebutuhan khusus sebagai warga negara Indonesia. "Sekolah penyelenggaraan pendidikan inklusif diperuntukkan bagi peserta didik yang berkebutuhan khusus, sebagai wujud disamaratakannya pendidikan dan pengajaran melalui cara mencerdaskan bangsa yang selaras sesuai dengan pesan pendidikan bahwa adanya education for all (pendidikan untuk semua) sebagai salah satu usaha meningkatkan partisipasi anak-anak bersekolah (pemerataan kesempatan pendidikan)"(Nana, 2019).

Merdeka belajar merupakan bagian dari berubahnya sistem pendidikan dan pengajaran. Pemerintah dalam melakukan inovasi terhadap sistem pendidikan tentunya sistem pendidikan inklusif pun mesti diperhatikan. (Rizki Amalia \& Ulva, 2020), Demikian adanya dengan Sekolah Luar Biasa Kumala Indah Padangsidimpuan. Salah satu sekolah yang siap untuk melaksanakan program Merdeka Belajar. 


\section{Temuan Umum Penelitian}

Sekolah Luar Biasa (SLB) Kumala Indah Padangsidimpuan berdiri di kota Padangsidimpuan sejak tahun 2017. Latar belakang berdirinya disebabkan banyaknya anak yang berkebutuhan khusus di sekitar kota Padangsidimpuan yang tidak memperoleh pendidikan dan pengajaran di sekolah formal (Nuryaningsih, 2020b). Hal ini disebabkan jarak tempat tinggal peserta didik yang jauh dari lokasi Sekolah Luar Biasa (SLB) Negeri. Sekolah inklusi sangat jauh dan berlokasi di daerah kabupaten Tapanuli Selatan tepatnya di Angkola Timur. Sekolah inklusi lainnya berlokasi di kecamatan Hutaimbaru kota Padangsidimpuan yang membutuhkan jam perjalanan 1,5 jam. Jarak lokasi sekolah yang jauh menjadikan anak yang berkebutuhan khusus di sekitar kota Padangsidimpuan tidak bisa didaftarkan ke Sekolah Luar Biasa Negeri karena sistem zonasi (Situmeang, 2020).

Adanya program pemerintah dalam membuat sistem zonasi juga menjadi latar belakang lainnya didirikannya Sekolah Luar Biasa Kumala Indah. Selanjutnya latar belakang ini juga disebabkan bahwa sekolah inklusi di kabupaten Tapanuli Selatan Angkola Timur dan Kecamatan Hutaimbaru tidak memiliki tenaga pengajar yang berlatar pendidikan untuk anak berkebutuhan khusus(Nuryaningsih, 2020) Berdasarkan latar belakang inilah maka ada inisiatif untuk mendirikan Sekolah Luar Biasa di kota Padangsidimpuan. (Ariyanti, 2020). Inisiatif mendirikan sekolah inklusi ini atas ide ibu Nuryaningsih dan dan ibu Kumala Indah Sayekti, sebagai bendahara Yayasan(Sayekti, 2020).Sekolah yang masih menyewa gedung ini sekarang sudah mulai membangun gedung baru di atas lahan 800 meter (Harahap, 2020). Gedung sekolah didirikan di atas bangunan 200 meter. dan sudah mendapat izin dari pemerintah daerah setempat dengan bukti notaris. Sekolah Luar Biasa (SLB) Kumala Indah kota Padangsidimpuan jumlah siswanya sekarang 21 orang(Maharani, 2020). Berikut data tersebut:

Tabel 1

Data Siswa SLB Kumala Indah Kota Padangsidimpuan

\begin{tabular}{|l|l|l|}
\hline \multicolumn{1}{|c|}{ Nama } & JK & \multicolumn{1}{c|}{ Berkebutuhan Khusus } \\
\hline Arfan Sahroni Siregar & L & Gangguan Penglihatan \\
\hline Inasari & P & Gangguan Penglihatan \\
\hline Laila Dalimunthe & P & Gangguan Penglihatan \\
\hline Cyndia Rahma Dalimunthe & P & Gangguan Reterdasi Mental \\
\hline Nikmat Ramadhani Lubis & P & Gangguan Reterdasi Mental \\
\hline Novita sari Harahap & P & Gangguan Reterdasi Mental \\
\hline Nuatika Lubis & P & Gangguan Reterdasi Mental \\
\hline Sahat Anggina Batubara & L & Gangguan Reterdasi Mental \\
\hline Sophiani Siregar & P & Gangguan Reterdasi Mental \\
\hline Tamrin & L & Gangguan Reterdasi Mental \\
\hline Tulus & L & Gangguan Reterdasi Mental \\
\hline Royhan Habibi Siregar & L & Gangguan Gerak \\
\hline Wahyu Bilal Siregar & L & Gangguan Gerak \\
\hline Akmal Rasyid Syakir & L & Autis \\
\hline Hamdan Irsyadi Nasution & L & Autis \\
\hline Yuda Ardani & L & Autis \\
\hline Frans Cristian & L & Gangguan Reterdasi Mental \\
\hline Mazdalifa Pane & P & Autis \\
\hline Ismul Anugrah Siregar & L & Autis \\
\hline Muhammad Syahdin & L & Gangguan Reterdasi Mental \\
\hline Ikhdza Fadhiel Muhammad & L & Autis \\
\hline
\end{tabular}


Siswa tersebut disebar dalam 7 rombongan belajar. 7 rombongan belajar terdiri dari: 5 rombongan belajar tingkat Sekolah Dasar dan 2 rombongan belajar tingkat Sekolah Menengah Pertama. Seluruh rombongan belajar didik oleh 5 guru sebagai guru tetap yayasan. Guru-guru di Sekolah Luar Biasa (SLB) Kumala Indah berlatar belakang pendidikan Sarjana dan Sekolah Menengah Atas, berikut data guru tersebut:

Tabel 2

Data guru tetap yayasan Sekolah Luar Biasa Kumala Indah

\begin{tabular}{|l|l|l|l|l|}
\hline Nama & JK & SStatus & Jabatan & Pendidikan Terakhir \\
\hline Safar Harian Soleh & L & GTY & Kepala Sekolah & S1 \\
\hline Novalina Situmeang & P & GTY & Guru & SMA \\
\hline Nurmala Matondang & P & GTY & Guru & S1 \\
\hline Hari Yanti Tambunan & P & GTY & Guru & S1 \\
\hline Dahnita Sari Nst & P & GTY & Guru & SMA \\
\hline
\end{tabular}

(Indah, 2020)

Anak berkebutuhan khusus di Sekolah Luar Biasa (SLB) Kumala Indah kota Padangsidimpuan belajar di ruang kelas yang dilengkapi sarana dan prasarana yang mendukung proses pembelajaran. Berdasarkan data yang diperoleh bahwa sarana dan prasarana adalah mendukung proses pembelajaran, seperti meja dan kursi terapi berformat melingkar(Soleh, 2020). Sarana lainnya adalah sarana bermain anak seperti perosotan, jungkat-jungkit, trampolin dan ayunan (Tambunan, 2020). Sarana prasarana di dalam kelas juga disediakan di mana sarana dan prasarana tersebut sesuai dengan tema dan sub tema materi pembelajaran, seperti: Gambar Lambang Sila Pancasila, Gambar-gambar alat dan bahan pembenihan sayur, Gambar kegiatan menjaga kebersihan halaman rumah, Video merawat tumbuhan, Video merawat hewan, Video gerakan senam statis, Video gerakan senam dinamis, Simbol Sila Pancasila, Perkalian Bilangan Asli, gambar benda - benda tajam dan gambar benda - benda runcing, baju berkancing, Video merawat tanda akan turun hujan, Video cara pencegahan banjir(Nasution, 2020).

Sarana prasarana tersebut sekaligus dijadikan sebagai media pembelajaran. Media pembelajaran ini sangat mendukung proses pembelajaran kepada penilaian asessmen kompetensi minimum dan penilaian karakter. "Penilaian asesement dalam upaya menilai kemaampuan peserta didik dalam mencapai sejumlah standar kompetensi dan kompetensi dasar yang dirumuskan dalam Rencana Program Pengajaran (RPP) masing-masing kelas. Pelaksanaan penilaian kelas, merupakan suatu proses yang dilakukan melalui langkah-langkah perencanaan, penyusunan alat penilaian, pengumpulan informasi melalui sejumlah bukti untuk menunjukkan pencapaian hasil belajar peserta didik"(Hamzah et al., 2020). Penilaian kelas ini dikembangkan salah satunya melahirkan penilaian sikap. Penilaian sikap dengan melakukan survei karakter. Untuk lebih rincinya hasil penelitian tentang merdeka belajar bagi anak berkebutuhan khusus berikut dideskripsikan dalam narasi temuan khusus.

\section{Temuan Khusus Penelitian}

Program merdeka belajar yang memuat 4 kebijakan, dapat terlihat di Sekolah Luar Biasa Kumala Indah kota Padangsidimpuan. Keempat kebijakan tersebut yang sedang berlangsung dilaksanakan adalah kebijakan tentang zonasi Penerimaan Peserta Didik Baru (PPDB) dan pelaksanaan penilaian hasil belajar dengan indikator Asesmen Kompetensi Minimum dan Survei Karakter sebagai wujud ditiadakannya pelaksanaan Ujian Nasional 2021. Sekolah Luar Biasa Kumala Indah kota Padangsidimpuan telah memberlakukannya bagi Anak Berkebutuhan Khusus.(Matondang, 2020). Berikut deskripsi temuan khusus penelitian ini: 


\section{Sistem Penerimaan Peserta Didik Baru (PPDB) Sekolah Luar Biasa (SLB) Kumala Indah kota Padangsidimpuan}

Sistem Penerimaan Peserta Didik Baru (PPDB) di Sekolah Luar Biasa (SLB) Kumala Indah kota Padangsidimpuan telah melaksanakan sistem zonasi. Pelaksanaan sistem zonasi ini mengingat banyaknya peserta didik yang berkebutuhan khusus di sekitar kota Padangsidimpuan. Jumlah peserta didik yang berkebutuhan khusus tidak semuanya dapat tertampung mengingat Sekolah Luar Biasa (SLB) Kumala Indah kota Padangsidimpuan belum memenuhi ruang kelas milik sendiri. (Sayekti, 2020). Dalam hal ini Sekolah Luar Biasa (SLB) Kumala Indah merujuk kepada program pemerintah Merdeka Belajar untuk melaksanakannya dengan memberlakukan jalur zonasi. Jalur zonasi sesuai dengan presentase, dimana “jalur zonasi: minimal 50\%, jalur afirmasi: minimal 15\%, jalur perpindahan: maksimal 5\%, Jalur prestasi (sisanya 0-30\%, disesuaikan dengan kondisi daerah)"(Tohir, 2019).

Perberlakuan zonasi Penerimaan Peserta Didik Baru (PPDB) dalam rangka upaya pemerintah daerah menentukan proporsi final dan menetapkan wilayah zonasi sehingga ada pemerataan akses. Pemerataan akses peserta didik dalam mengakomodir kualitas pendidikan. Adapun distribusi zonasi penerimaan peserta didik baru di Sekolah Luar Biasa (SLB) Kumala Indah kota Padangsidimpuan jalur zonasi: 10 siswa, jalur afirmasi: 2 siswa, jalur perpindahan: maksimal 1 orang, jalur prestasi 9 siswa(Soleh, 2020).

Dengan demikian bahwa Sekolah Luar Biasa (SLB) Kumala Indah kota Padangsidimpuan dalam Penerimaan Peserta Didik Baru (PPDB) telah mengimplementasikan Merdeka Belajar ini bagi anak berkebutuhan khusus sesuai dengan ketentuan Peraturan Menteri Pendidikan dan Kebudayaan. Anak berkebutuhan khusus telah memperoleh kebebasan dalam memilih lokasi sekolah tempat belajar. Dalam hal ini Merdeka belajar bagi anak berkebutuhan khusus di Sekolah Luar Biasa (SLB) Kumala Indah kota Padangsidimpuan telah terekplorasi secara maksimal dalam upaya menampung kemampuan dan potensi yang dimiliki oleh peserta didik (Mustaghfiroh, 2020). Anak berkebutuhan khusus melalui merdeka belajar sistem zonasi secara alamiah memiliki kemampuan dan potensi untuk dikembangkan secara natural. Lembaga pendidikan dapat menjadi laboratorium pendidikan untuk perubahan anak berkebutuhan khusus. Aktivitas di lembaga pendidikan dapat dikooperasikan secara maksimal dengan lokasi, jarak tempuh lokasi rumah peserta didik.

Dalam hal ini melalui merdeka belajar juga bertanggung jawab membina peserta didik agar dewasa, berani, mandiri dan berusaha sendiri. Dengan demikian nuansa pendidikan semestinya diupayakan agar memberikan kesempatan kepada peserta didik untuk selalu berpikir mandiri dan kritis dalam menemukan jati dirinya. Dalam konteks ini, yang terpenting bukanlah memberikan pengetahuan positif yang bersifat taken for granted kepada peserta didik, melainkan bagaimana mengajarkan kepada peserta didik agar memiliki kekuatan bernalar. Salah satu upaya yang dapat dilakukan adalah dengan memberikan kemerdekaan kepada peserta didik untuk terlibat langsung dalam proses pembelajaran dan transfer keilmuan.

Dalam hal ini anak yang berkebutuhan khusus, telah diberi kesempatan dan kebebasan untuk belajar sesuai lokasi tempat anak tersebut berada. Anak berkebutuhan khusus dapat didorong agar senantiasa berpikir mandiri dan kritis dalam menemukan jati dirinya, karena sekolah di tempat yang dituju oleh keinginan hatinya. Anak berkebutuhan khusus dapat melaksanakan proses pembelajaran dengan semaksimal mungkin dimana peserta didik itu sendiri telah diberikan kemerdekaaan untuk diterima di suatu sekolah. Penerimaan peserta didik (PPDB) merupakan awal keberhasilan anak berkebutuhan khusus menuju jenjang sekolah yang dipilih 
(Wahdan Nadjib Habibi, 2019), sehingga orang tua siswa pun mendorong anak-anak mereka belajar yang maksimal karena adanya pemerataan akses pendidikan (Ihwanuddin, 2020). Anak berkebutuhan khusus yang telah memperoleh kesempatan untuk mendapatkan pemerataan akses pendidikan menjadi pendorong juga bagi guru untuk menggaungkan program merdeka belajar. Guru dapat memulainya dalam proses pembelajaran dengan membuat Rencana Program Pengajaran (RPP) yang nantinya sebagai rujukan dalam mengaplikasikan assessment kompetensi minimal dan survei karakter peserta didik.

\section{Asesemen Kompetensi Minimum dan Survei Karakter bagi Anak Berkebutuhan Khusus Sekolah Luar Biasa (SLB) Kumala Indah kota Padangsidimpuan}

Peserta didik di Sekolah Luar Biasa (SLB) sudah mengganti Ujian Nasional menjadi assesmen kompetensi minimal dan survei karakter. Hal ini dilakukan untuk menggaungkan Merdeka belajar bagi anak berkebutuhan khusus. Dalam asesmen dibutuhkan Rencana Program Pengajaran sebagai bahan rujukan. Adapun tampilan Rencana Program Pengajaran (RPP) Sekolah Luar Biasa (SLB) Kumala Indah Padangsidimpuan K13 yakni pada bagian langkah-langkah kegiatan pembelajaran peserta didik telah untuk berlatih praktek. Peserta didik diarahkan mempresentasekan hasil kerja kemudian disimpulkan sebagai penilaian pembelajaran. Penilaian pembelajaran dilakukan setelah mengikuti proses pembelajaran. Penilain pembelajaran berdasarkan prosedur dan alat penilaian untuk mencapai tujuan pembelajaran.(Hamzah et al., 2020). Sedangkan dalam RPP Merdeka Belajar mencakup identitas pembelajaran, tujuan pembelajaran, langkah-langkah kegiatan pembelajaran yang terdiri dari Alat dan bahan pembelajaran, pertanyaan, kesimpulan pembelajaran dan penilaian. Serta bagian penutup dilengkapi dengan tandatangan kepala sekolah dan guru mata pelajaran.

Kemampuan peserta didik terlihat dengan adanya rekapitulasi dari penilaian pembelajaran. Guna mengetahui perkembangan pembelajaran anak berkebutuhan khusus maka dibutuhkan adanya proses asessmen. Proses asessmen adalah untuk mengetahui profil siswa ABK. (Qomarudin et al., 2019). Profil siswa anak berkebutuhan khusus inilah dituliskan di dalam survei karakter. Survei karakter memuat tentang kemampuan dasar yang harus dikuasai oleh peserta didik. Survei karakter dan asesmen kemampuan minimum siswa tetap memperhatikan kognitif dan pemahaman materi. Dalam pelaksanaan asesmen kemampuan minimum dan survei karakter di Sekolah Luar Biasa (SLB) Kumala Indah kota Padangsidimpuan maka guru penting melakukan beberapa pembaharuan antara lain: "mengintegrasikan konsep asesmen kompetensi, diskusi dan brainstorming pembelajaran inovatif yang berbasis literasi dan numerasi, evaluasi dampak pembelajaran konservatif, aktualisasi bentuk pembelajaran inovatif sebagai bentuk asesmen kompetensi dan, refleksi pada studi model literasi dan numerasi yang dihasilkan siswa.(Nehru, 2019).

Pelaksanaan asesmen kompetensi merupakan langkah pertama bagi pendidik melaksanakannya dalam skala kecil pada satuan pendidikanya. Khusus untuk anak berkebutuhan khusus asesmen kemampuan minimum harus selalu dipantau secara terus menerus dan berkelanjutan. Di mana batasan asesmen untuk mendapat suatu kesimpulan dalam penentuan profil dan karakter harus melakukan proses pengumpulan informasi tentang penampilan anak berkebutuhan khusus yang bersangkutan.(Marlina, 2015). Disimpulkan bahwa asesmen kemampuan minimum dan surve karakter berupaya menciptakan pendidikan berbasis kompetisi dan berbasis karakter.(Muhajir, Almaidah. Kurni, 2019) Peserta didik yang berkebutuhan khusus penting direalisasikan melalui inovasi perangkat pembelajaran sesuai dengan format Rencana Program Pengajaran Merdeka Belajar. 


\section{SIMPULAN}

Merdeka Belajar merupakan salah satu langkah untuk memajukan pendidikan. Bangsa yang maju adalah bangsa dimana semua warga negaranya dapat mengenyam pendidikan. Bangsa yang maju juga bangsa yang mampu memberikan kontribusi pemikiran melalui kebijakan-kebijakan pendidikan. Kebijakan pendidikan yang dimaksud mampu memberikan perbaikan dan peningkatan. Salah satu kebijakan pendidikan di Indonesia adalah Merdeka Belajar. Merdeka Belajar mempunyai 4 opsi yang harus dilakukan perubahan, yaitu digantinya Ujian Sekolah Berbasis Nasional (USBN) menjadi asesmen sebagai alasan adanya pembatasan penerapan Undang-Undang Sistem Pendidikan Nasional yang memberikan keleluasaan bagi sekolah untuk menentukan kelulusan. Digantinya Ujian Nasional (UN) dengan Asesmen Kompetensi Minimum dan Survei Karakter. Kompetensi minimum siswa diukur dari aspek literasi dan numerasi. Format Rencana Pelaksanaan Pembelajaran (RPP) dirampingkan. Rencana Pelaksanaan Pembelajaran (RPP) berisi tujuan pembelajaran, kegiatan pembelajaran dan asesmen. Zonasi Penerimaan Peserta Didik Baru (PPDB) lebih fleksibel untuk mengakomodasi ketimpangan akses dan kualitas di berbagai daerah. Merdeka Belajar di Sekolah Luar Biasa (SLB) Kumala Indah kota Padangsidimpuan terus berupaya untuk melaksanakan keempat opsi proram yang dicanangkan Menteri Pendidikan dan Kebudayaan tersebut. Dalam hal ini sedang dan akan dilakukan tahap awal adalah pelaksanaan asesmen kompetensi minimum dan survei karakter serta zonasi Penerimaan Peserta Didik Baru (PPDB) . Dua opsi pertama dan terakhir ini sebagai langkah awal memberdayakan sekolah inklusif dalam mengembangkan numerasi dan literasi siswa yang berkebutuhan khusus. Serta mengembangkan keterampilan pembelajaran guru anak yang berkebutuhan khusus melalui Rencana Program Pengajaran (RPP) yang lebih fokus menggali potensi dan mengembangkan seta mensurvei karakter siswa.

\section{REFERENSI}

Adit, A. (2019). Gebrakan "Merdeka Belajar", Berikut 4 Penjelasan Mendikbud Nadiem Artikel ini telah tayang di Kompas.com dengan judul "Gebrakan 'Merdeka Belajar', Berikut 4 Penjelasan Mendikbud Nadiem”,. Kompas. https://edukasi.kompas.com/read/2019/12/13/17485331/un-tidakdihapus-tapi-

Anggito, Albi \& Setiawan, J. (2018). Metodologi penelitian kualitatif (p. 268). Jejak. https://books.google.co.id/books?id=59V8DwAAQBAJ\&printsec $=$ frontcover\&dq=meto $\mathrm{de}+$ penelitian + sugiyono\&hl=id\&sa=X\&ved=0ahUKEwio3KSekfzgAhXGXCsKHSmxAd $\mathrm{gQ6AEINTAD \#} \#_{\mathrm{v}}=$ onepage $\& \mathrm{q}=$ metode penelitian sugiyono\&f$=$ false

Ariyanti. (2020). Wawancara, Ketua Yayasan.

Asfi Manzilati. (2017). Metodologi Penelitian Kualitatif: Paradigma, Metode, dan Aplikasi (p. h.11.). Universitas Brawijaya Press. https://books.google.co.id/books?hl=en\&lr=\&id=7FlVDwAAQBAJ\&oi=fnd\&pg=PR5\& $\mathrm{dq}=$ subyek + dan + obyek + penelitian\&ots $=$ Y57y9h_rf_\&sig=DIZKusqDHiczY9UXiM2ids sh6nI\&redir_esc $=\mathrm{y} \# \mathrm{v}=$ onepage $\& \mathrm{q}=$ subyek dan obyek penelitian $\& \mathrm{f}=$ false

Badiah, L. I., Jauhari, M. N., \& Sambira, S. (2020). Peningkatan Keterampilan Guru Paud Dalam Menyusun Program Pembelajaran Individual Anak Berkebutuhan Khusus Di PAUD Permata Bunda. SPEED Journal: Journal of Special Education, 3(2), 95-100. 
https://doi.org/10.31537/speed.v3i2.287

Edaran, S. M. N. 14 T. 2019. (2019). Format RPP. Kementerian Pendidikan Dan Kebudayaan.

Hamzah, S. I., Djuko, R. U., \& Juniarti, Y. (2020). Asesmen terhadap Anak Berkebutuhan Khusus ( Abk ) Strategi Yang Dapat Membuat Peserta Didik Nyaman Dalam Mengikuti Proses. Jambura Early Childhood Education Journal, 2(2), 109-123.

Harahap, S. E. (2020). Wawancara, Pengawas Yayasan.

Ihwanuddin. (2020). Wawancara, Orang tua siswa.

Indah, D. S. S. K. (2020). Dokumetasi.

Indonesia, P. R. (2003). Undang-Undang Republik Indonesia Nomor 20 Tahun 2003 Tentang Sistem Pendidikan Nasional. In Sekretaris Negara Republik Indonesia (Vol. 19, Issue 8). https://kelembagaan.ristekdikti.go.id/wpcontent/uploads/2016/08/UU_no_20_th_2003.pdf

Luthfiyah, M. F. \&. (2018). Metodologi penelitian: penelitian kualitatif, tindakan kelas \&sstudi kasus (p. 234). Jejak.

Maharani, L. (2020). Wawancara, Sekretaris Yayasan.

Marlina. (2015). No Asesemen Anak Berkebutuhan Khusus Pendekatan Psikoedukasional. UNP Press Padang.

Matondang, N. (2020). Wawancara,Guru SLB Kumala Indah kota Padangsidimpuan.

Muhajir, Almaidah. Kurni, Y. (2019). Analisis Isi Pesan Pidato Mendikbud Nadiem Anwar Makarim Dalam Memperingati Hari Guru.

Mustaghfiroh, S. (2020). Konsep "Merdeka Belajar" Perspektif Aliran Progresivisme John Dewey. Jurnal Studi Guru Dan Pembelajaran, $3(1$ SE-Articles), 141-147. https://doi.org/10.30605/jsgp.3.1.2020.248

Nana, A. F. \&. (2019). Penerapan Media Pembelajaran Untuk Anak Berkebutuhan Khusus Dengan Berbantuan Model POE2WE. Journal of Chemical Information and Modeling, 53(9), 1689-1699. https://doi.org/10.1017/CBO9781107415324.00

Nasution, D. S. (2020). W awancara, Guru SLB Kumala Indab kota Padangsidimpuan.

Nehru, N. A. (2019). Asesmen Komptenesi Sebagai Bentuk Perubahan Ujian Nasional Pendidikan Indonesia: Analisis Dampak dan Problem Solving Menurut Kebijakan Merdeka Belajar. Journal of Chemical Information and Modeling, 53(9), 1689-1699. https://doi.org/10.1017/CBO9781107415324.004

Nursyaidah. (2018). Metodologi Penelitian Disertai Dengan Contoh Penerapannya Dalam Penelitian (p. h.153).

Nuryaningsih. (2020a). Wawancara, Kepala Sekolah. 
Nuryaningsih. (2020b). Wawancara, Pembina Yayasan.

Qomarudin, M., Basir, M. A., \& Indah, D. (2019). Model Kolaborasi Identifikasi Dini Anak Berkebutuhan Khusus ( ABK) Untuk Menunjang Pelaksanaan Pendidikan Inklusi. Sendika, 3(November), 91-100.

Rizki Amalia \& Ulva, M. (2020). Proses Pembelajaran Matematika Pada Anak Berkebutuhan Khusus (Autisme) di Sekolah Inklusif. Journal On Teacher Education, 1(2), 9-19.

Sayekti, K. I. (2020). Wawancara, Bendahara Yayasan.

Situmeang, N. (2020). Wawancara, Wakil Kepala Sekolah bidang Kurikulum.

Soleh, S. H. (2020). W awancara, Kepala Sekolah SLB Kumala Indah kota Padangsidimpuan.

Tambunan, H. Y. (2020). W awancara guru SLB Kumala Indah kota Padangsidimpuan.

Tohir, M. (2019). Merdeka Belajar. Kementerian Pendidikan Dan Kebudayaan,

Wahdan Nadjib Habibi, S. N. F. (2019). Persepsi Masyarakat dan Dampak Sistem Zonasi Untuk Jenjang Sekolah Dasar di Kecamatan Serengan Kota Surakarta. Proceedings of the 20th USENIX Security Symposium, 6(2), https:// doi.org/10.23917/ppd.v1i2.10151 